\title{
Effect of a cyanobacterial diet on the competition between rotifers: a case study in Lake Albufera of Valencia, Spain
}

\author{
S.S.S. Sarma ${ }^{1}$, S. Nandini ${ }^{1}$, M.R. Miracle ${ }^{\dagger}$ and E. Vicente ${ }^{2, *}$ \\ ${ }^{1}$ Laboratorio de Zoología Acuática, División de Investigación y Posgrado, Universidad Nacional Autónoma de México, \\ Campus Iztacala, Av. de los Barrios \#1, Los Reyes, Iztacala, Tlalnepantla, CP 54090. Estado de México, Mexico. \\ 2 Dept. Microbiologia i Ecologia \& ICBiBE, Universitat de València, 46100-Burjassot (Valencia), Spain. \\ $\dagger$ Deceased. \\ * Corresponding author: eduardo.vicente@uv.es
}

Received: $12 / 11 / 18 \quad$ Accepted: $27 / 11 / 18$

\begin{abstract}
Effect of a cyanobacterial diet on the competition between rotifers: a case study in Lake Albufera of Valencia, Spain

Brachionus havanaensis is predominantly distributed in the Nearctic and Neotropical regions. It is now found even in the Palearctic and Oriental regions. During the summer of 2015 we found high densities ( $>500$ ind./1) of this species and low numbers of Brachionus angularis in Lake Albufera where the cyanobacterium (Microcystis aeruginosa) was dominant in the phytoplankton community. We hypothesized that the cyanobacterium was toxic to B. angularis but not to B. havanaensis hence the latter would outcompete the former in the presence of this cyanobacterium. To test the hypothesis, we conducted competition experiments between two coexisting rotifer species (B. angularis and B. havanaensis) from the Lake Albufera of Valencia using as food the green alga (Nannochloropsis oculata) and sonicated colonies of M. aeruginosa (single cells), separately and together (1:1 ratio based on biomass). The competition experiments using the population growth approach showed that $B$. havanaensis in controls had higher population abundances than $B$. angularis. However, when grown both together, $B$. havanaensis had a reduced population growth (nearly $50 \%$ ) in relation to B. angularis, in the absence of Microcystis in the diet. This reduced growth was more than that in the treatment of B. havanaensis alone when grown on a mixed diet of Microcystis and Nannochloropsis oculata. Brachionus havanaensis in all treatments (alone or in the presence of B. angularis) died completely when cultured on $100 \%$ M. aeruginosa. The population growth rates of $B$. angularis, alone or in competition with B. havanaensis, were similar when Microcystis was excluded from the diet. However, Microcystis alone or together with Nannochloropsis was highly detrimental for the population growth of B. angularis. Our results showed the differences in the competitive outcome between the rotifers depending on the presence or absence of toxic cyanobacteria in the diet. Our study also showed that an exclusive diet of this cyanobacterium was toxic to both rotifers.
\end{abstract}

Key words: Brachionus, Rotifera, Population dynamics, Microcystis, Nannochloropsis

\section{RESUMEN}

Efecto de la dieta con cianobacterias en la competencia entre rotíferos: un caso de estudio en la laguna de la Albufera de Valencia, España

Brachionus havanaensis se distribuye predominantemente en las regiones Neártica y Neotropical. Ahora se encuentra incluso en las regiones Paleártica y Oriental. Durante el verano de 2015, encontramos altas densidades (> 500 ind./l) de esta especie y bajas abundancias de Brachionus angularis en la laguna de la Albufera, donde la cianobacteria (Microcystis aeruginosa) fue dominante en la comunidad de fitoplancton. Nuestra hipótesis fue que la cianobacteria era tóxica para B. angularis pero no para B. havanaensis, por lo que este último superaría al primero en presencia de dicha cianobacteria. Para probar la hipótesis, realizamos experimentos de competencia entre estas dos especies de rotiferos (B. angularis $y$ B. havanaensis) que coexisten en la laguna de la Albufera de Valencia utilizando como alimento el alga verde (Nannochloropsis oculata) y colonias sonicadas de M. aeruginosa (células individuales) por separado y juntas (en relación 1:1 basada en biomasa). Los experimentos de competencia basados en el seguimiento del crecimiento poblacional mostraron que en los controles $\mathrm{B}$. havanaensis conseguía 
un mayor crecimiento poblacional que B. angularis cuando lo hacian separadamente. Sin embargo, cultivándolos ambos juntos, B. havanaensis tuvo una reducción del crecimiento poblacional (casi $50 \%$ ), con respecto a $\mathrm{B}$. angularis, en ausencia de Microcystis en la dieta. Esta reducción del crecimiento fue mayor que en el tratamiento de B. havanaensis individualmente, cuando se cultivó con una dieta mixta de Microcystis y Nannochloropsis oculata. Brachionus havanaensis en todos los tratamientos (solos o en presencia de B. angularis) murió completamente cuando se cultivó en $100 \%$ de M. aeruginosa. Las tasas de crecimiento poblacional de $\mathrm{B}$. angularis, solos o en competencia con $\mathrm{B}$. havanaensis, fueron similares cuando se excluyó a Microcystis de la dieta. Sin embargo, el cultivo solo con Microcystis o junto con Nannochloropsis fue altamente perjudicial para el crecimiento poblacional de B. angularis. Nuestros resultados mostraron el diferente resultado de los experimentos de competencia entre estos dos rotiferos en función de la presencia o ausencia de cianobacterias tóxicas en la dieta. Nuestro estudio también mostró que una dieta exclusiva de esta cianobacteria era tóxica para ambas especies de rotíferos.

Palabras clave: Brachionus, Rotifera, dinámica poblacional, Microcystis, Nannochloropsis

\section{INTRODUCTION}

Competition in aquatic ecosystems is an important natural process that structures the plankton composition (Vanni, 1986). Studies on the competitive interactions within the zooplanktonic groups are usually conducted using large species such as cladocerans (Smith \& Cooper, 1982), which differ from the competitive outcome among the smaller sized zooplankton such as rotifers (Gilbert, 1985). For example, cladocerans are capable of breaking and then feeding on toxic filamentous cyanobacteria which rotifers are incapable of (Sikora \& Dawidowicz, 2017). Therefore, often due to the mechanical limitation of consuming cyanobacteria, rotifers are incapable of competing with cladocerans. Even when the toxic cyanobacterial colonies are sonicated to single cells and offered as a diet to competing rotifers and cladocerans, the latter usually dominate due to their higher food gathering ability and the mechanical damage (from the powerful swimming currents) they inflict to the rotifer eggs (MacIsaac \& Gilbert, 1989). Therefore, it becomes evident that when unequally sized zooplankton groups compete, the smaller groups become competitively inferior especially under higher food levels (Sarma et al., 1996).

When two similar sized zooplankton species compete for food, the outcome depends on many different factors including the relative feeding and filtration rates, the magnitude of population growth rate and initial densities of the competing species (Sarma et al., 1999, Nandini et al., 2007). Also, if the medium contains toxic cyanobacteria, then the relative tolerances of competing species to the toxins are also crucial in deciding the outcome (Alva-Martínez et al., 2007). For example, when two similar sized rotifers, Brachionus havanaensis and Brachionus calyciflorus were cultured together on Microcystis mixed with green alga at different proportions we observed a more adverse effect on B. calyciflorus than on $B$. havanaensis (Alva-Martínez et al., 2009). However, if the competing species have similar sensitivities to toxins, then the competitive outcome is independent of the toxic cyanobacteria. For example, Lin et al. (2014) have shown that two rotifers of the family Brachionidae, Plationus patulus and Brachionus havanaensis had similar sensitivities to sonicated cells of a toxic strain of Anabaena sp. Both species failed to grow in the presences of this cyanobacterium, and thus competition was not influenced by the toxins. Therefore, although cyanobacterial toxicity influences zooplankton growth rates, it is not necessarily the deciding biotic factor that determines the competitive outcome among zooplankton species.

Lake Albufera of Valencia is a shallow hypertrophic waterbody on the Mediterranean Coast of Spain. The plankton of this waterbody has been extensively studied over three decades (Vicente $\&$ Miracle, 1992; Romo et al., 2008). The phytoplankton is composed of toxic colonial cyanobacteria, mainly Microcystis aeruginosa, while the rotifers are dominated by the genus Brachionus. Among the species of Brachionus, B. havanaensis is common in American epicontinental waters (Segers, 2008). Its natural abundances can be as high as 1000 ind./1 (Nandini et al., 2016). It has the ability to reach extremely high population abundances (up to $600 \mathrm{ind} . / \mathrm{ml}$, under experimental conditions (Pavón-Meza et al., 2004) and to 
resist toxic effects of the colonial cyanobacteria including Microcystis spp. Though its occurrence has been reported in temperate European water-bodies (Segers, 2008), it is generally found in low abundances $(<50$ ind./1). However, during the summer 2015, we found very high densities of B. havanaensis ( $>500$ ind./l) but low abundances of another brachionid rotifer $B$. angularis in Lake Albufera. The phytoplankton of the lake at that time contained blooms of Microcystis aerugino$s a$. Therefore we hypothesized that low abundances of $B$. angularis were due to the combined effect of competitive pressure from $B$. havanaensis and the toxic effects of M. aeruginosa.

The aim of the study was, therefore, to test which of the two natural forces, competition from congeners or toxicity from Microcystis had a higher impact on the population growth of $B$. havanaensis and $B$. angularis.

\section{MATERIAL AND METHODS}

Zooplankton samples were collected using a plankton net (pore size $50 \mu \mathrm{m}$ ) from Lake Albufera by filtering about $50 \mathrm{~L}$ of water. The phytoplankton, dominated by M. aeruginosa, was separately $(100 \mathrm{~L})$ collected using a plankton net and stored in the dark at $4{ }^{\circ} \mathrm{C}$ in a temperature-controlled chamber. From the live zooplankton samples we isolated a few individuals of Brachionus havanaensis and Brachionus angularis using stereomicroscope in the laboratory. From these, we established a clonal culture for each rotifer starting with a single female. The rotifers were fed the green alga Nannochloropsis oculata at a density of $0.5 \times 10^{6} \mathrm{cells} / \mathrm{ml}$ and maintained in reconstituted moderately hard water (EPA medium). This medium was prepared by dissolving $96 \mathrm{mg} \mathrm{NaHCO} 3,60 \mathrm{mg} \mathrm{CaSO} 4,60$ $\mathrm{mg} \mathrm{MgSO} 4$ and $4 \mathrm{mg} \mathrm{KCl}$ in one litre of distilled water (Weber, 1993). Nannochloropsis oculata was axenically batch-cultured in $2 \mathrm{~L}$ glass flasks using Bold's medium (Borowitzka \& Borowitzka, 1988). When the alga reached the log phase (after seven days following inoculation at a density of $0.1 \times 10^{6}$ cells $/ \mathrm{ml}$ ), it was harvested and concentrated by centrifugation at $3000 \mathrm{rpm}$ for $5 \mathrm{~min}$. The concentrated alga was rinsed and re-suspended in a small volume $(5 \mathrm{ml})$ of distilled water. The density of the harvested alga was estimated using a Neubauer haemocytometer.

For obtaining the sonicated cells of $M$. aeruginos $a$, we harvested the floating colonial cyanobacteria from the cold-chamber by syphoning using a Pasteur pipette. Later, the concentrated colonial M. aeruginosa was filtered using different meshes to remove large zooplanktonic organisms and smaller phytoplankton cells. The remaining cyanobacterial composition showed more than $93 \% M$. aeruginosa which was sonicated for four minutes at $20 \mathrm{kHz}$. Microscopic observations of the sonicated cells revealed that more than $90 \%$ of the biomass was in single-celled form of M. aeruginosa. The individual cell size of M. aeruginosa and that of Nannochloropsis oculata was similar $(4-5 \mu \mathrm{m})$. However, we used the biomass equivalent of M. aeruginosa, Nannochloropsis oculata or their mixed diet for rotifers in the test jars.

The population growth experiments for both rotifer species were conducted simultaneously. For the experiments, we used $40 \mathrm{ml}$ glass recipients as test jars, and each jar contained $30 \mathrm{ml}$ EPA medium with one of the chosen diet type and combination. In all we used 36 test jars: $B$. havanaensis alone, B. angularis alone and together (competition) $=3 \times$ food types $N$. oculata alone, $M$. aeruginos $a$ alone and their mixed diet $=$ $3 \times 4$ replicates for each treatment. Thus, into each test jars containing the chosen diet at the density of $0.5 \times 10^{6}$ cells $/ \mathrm{ml}$, we individually introduced one of the two rotifer species at an initial density of $1 \mathrm{ind} . / \mathrm{ml}$ (or both at a ratio of 1:1). The initial composition of rotifers in the test jars consisted of $80 \%$ neonates and $20 \%$ adults. The test jars were maintained in a temperature-controlled chamber set at $22 \pm 0.1{ }^{\circ} \mathrm{C}, \mathrm{pH}$ 7.0-7.4, and with photoperiod light-dark of 16-8 hours diffuse fluorescent illumination.

Following initiation of growth experiments, after every $24 \mathrm{~h}$ we counted the number of live rotifers in each jar, initially by total count, and as the density of the population increased to 50 ind./ml in some replicates, we used two aliquots of $1 \mathrm{ml}$ each. Following quantification of the rotifers density, we replaced them into a freshly prepared medium with an appropriate algal-cyanobacterial composition. 
Based on the data collected, we derived the rate of population increase $(r)$ per day using the exponential growth equation: $r=\left(\ln N_{t}-\ln N_{0}\right) / t$, where $N_{0}=$ initial rotifer density; $N_{t}=$ rotifer density after time $t$; and $t=$ time in days. In treatments where a peak of population abundance was not evident, the growth rate was calculated from the slope between $\ln N$ and time (Sibly \& Hone, 2002) and when growth did not occur, the $r$ was not derived.

The peak population density and the rate of population increase for each rotifer species were statistically treated using two-way ANOVA. For multiple comparisons, we used a post hoc (Tukey) test (SigmaPlot ver. 12).

\section{RESULTS}

Population growth curves of Brachionus havanaensis cultured separately and together with B. angularis fed Nannochloropsis oculata (100 $\%)$, sonicated Microcystis aeruginosa (100\%) or on the mixed diet (1:1 ratio of $N$. oculata: $M$. aeruginosa) differed depending on the treatment (Fig. 1). When cultured on $N$. oculata, in the presence or absence of competition from $B$. angu-
B. havanaensis alone

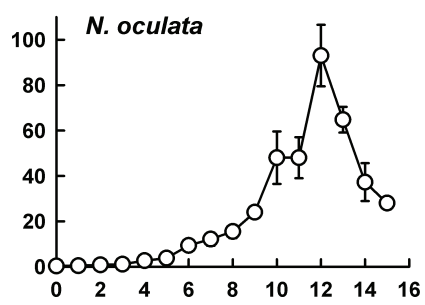

틀
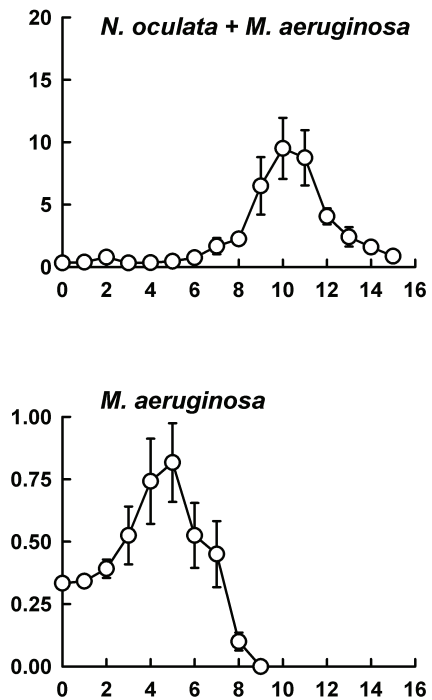

B. havanaensis $+B$. angularis
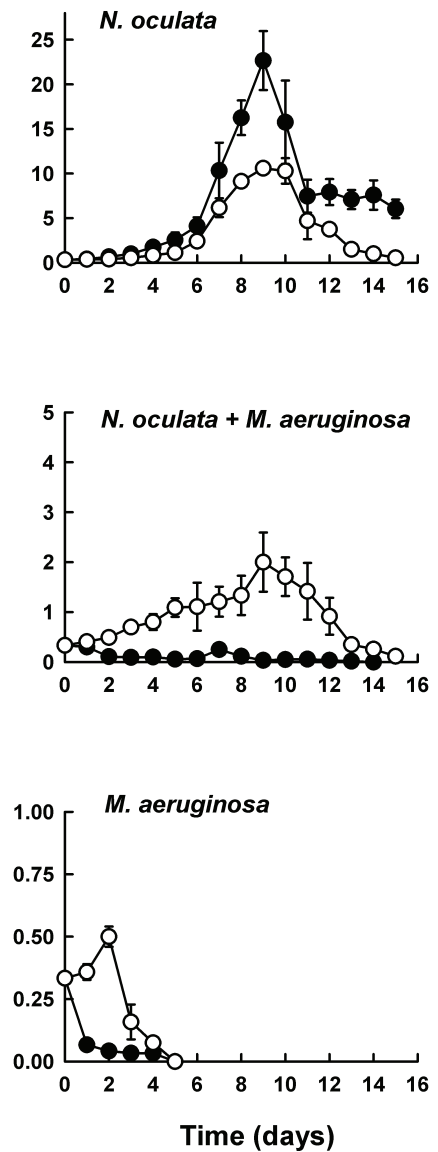

\section{B. angularis alone}
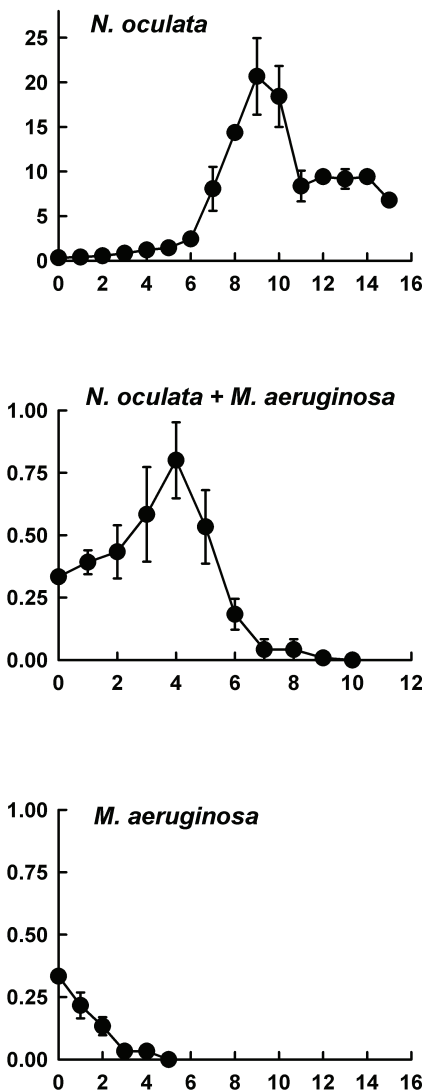

Figure 1. Population growth curves of Brachionus havanaensis and B. angularis cultured alone or together on Nannochloropsis oculata, sonicated cells of Microcystis aeruginosa or on the mixed diet. Shown are the mean \pm standard errors based on four replicates. Note the differences in the scale on Y-axis. Open circle: B. havanaensis; closed circle: B. angularis. Curvas de crecimiento poblacional de Brachionus havanaensis y $\mathrm{B}$. angularis cultivadas solas o juntas, usando Nannochloropsis oculata, células sonicadas de Microcystis aeruginosa o en la dieta mixta. Se muestran el promedio \pm errores estándar basados en cuatro repeticiones. Nótese las diferencias en la escala en el eje Y. Círculo abierto: B. havanaensis; Círculo cerrado: B. angularis. 
laris, B. havanaensis showed an initial lag phase of about four days, an exponential phase of about seven days and after that the population began to decline. With the inclusion of sonicated M. aeruginosa in the diet, $B$. havanaensis had a longer lag phase (6 days). On a diet of M. aeruginosa alone, $B$. havanaensis grew until 6 days and then declined but on this diet and the presence of the competitor the decline began after 3 days. The growth curves of $B$. angularis cultured on a diet of $N$. oculata, alone or in the presence of a competitor were similar. However, with the inclusion of $M$. aeruginosa, the population of $B$. angularis hardly grew beyond the inoculation density and when fed on an exclusive diet of $M$. aeruginosa, the populations of $B$. angularis completely collapsed by the fifth day.

Depending on the treatment and the test rotifer species, the peak population abundances of $B$. havanaensis and B. angularis varied from 1-95 and 1-23 ind./ml, respectively. The presence of a competitor or the toxic diet had differential effects on the maximal population densities achieved by the tested brachionid rotifers. For example, for B. havanaensis, the presence of $M$. aeruginosa (in the mixed diet) or the presence of competitor (in the absence of cyanobacteria) had a similar adverse effect on the peak population density. On the other hand, for $B$. angularis in the absence of $M$. aeruginosa, the presence of a competitor, B. havanaensis, had no adverse effect on the peak population densities.

The rates of population increase of $B$. havanaensis and $B$. angularis in treatments containing only $N$. oculata but without competition were 0.40 and $0.30 / \mathrm{d}$, respectively. When the mixed diet (Nannochloropsis and Microcyst$i s$ ) was offered as food, the growth rates of $B$. angularis, but not $B$. havanaensis, became negative. For either rotifer species, $100 \%$ M. aeruginosa did not permit sustained populations, and hence the derivation of growth rates was not feasible (Table 1).

Statistically, the peak population density of $B$. havanaensis was significantly influenced by the diet type, competition and their interaction $(p<$

Table 1. Data on the peak population abundance (ind. $/ \mathrm{ml}$ ) and the rate of population increase ( $r$ ) per day of B. havanaensis and B. angularis cultured separately and together in the presence $(\mathrm{N}+\mathrm{M}$ or $\mathrm{M})$ and absence $(\mathrm{N})$ of sonicated cells of $M$. aeruginosa. For each rotifer species data carrying the same alphabet are not significant $(p>0.05$, Tukey test $)$. N = Nannochloropsis oculata, $\mathrm{M}=$ Microcystis aeruginosa $; \mathrm{N}+\mathrm{M}=N$. oculata $+M$. aeruginosa $(50 \%$ each). Datos sobre la abundancia máxima de la población (ind./ml) y la tasa de aumento de la población (r) diaria de B. havanaensis $y$ B. angularis cultivados por separado y juntos en presencia $(N+M o$ ausencia $(N)$ de células sonicadas de M. aeruginosa. Para cada especie de rotiferos los daots que llevan la misma letra no son significativos ( $\mathrm{p}>0.05$, test de Tukey). $N=$ Nannochloropsis oculata, $M=$ Microcystis aeruginosa; $N+M=\mathrm{N}$. oculata $+\mathrm{M}$. aeruginosa $(a l$ $50 \%$ cada una).

\begin{tabular}{|c|c|c|c|c|c|c|}
\hline \multirow[t]{3}{*}{ Rotifer species } & \multicolumn{6}{|c|}{ Test conditions / Treatment } \\
\hline & \multicolumn{3}{|c|}{ Without competition } & \multicolumn{3}{|c|}{ With competition } \\
\hline & $\mathrm{N}$ & $\mathrm{N}+\mathrm{M}$ & $\mathrm{M}$ & $\mathrm{N}$ & $\mathrm{N}+\mathrm{M}$ & M \\
\hline & \multicolumn{6}{|c|}{ Peak population density (ind./ml) } \\
\hline B. havanaensis & $95 \pm 12^{\mathrm{a}}$ & $10 \pm 2^{\mathrm{b}, \mathrm{d}}$ & $1 \pm 0^{\mathrm{c}}$ & $11 \pm 1^{\mathrm{d}}$ & $2 \pm 1^{\mathrm{c}}$ & $1 \pm 0^{\mathrm{c}}$ \\
\hline B. angularis & $21 \pm 3^{\mathrm{a}}$ & $1 \pm 1^{\mathrm{b}}$ & $1 \pm 0^{\mathrm{b}}$ & $23 \pm 3^{\mathrm{a}}$ & $1 \pm 1^{\mathrm{b}}$ & $1 \pm 0^{\mathrm{b}}$ \\
\hline & \multicolumn{6}{|c|}{ Rate of population increase per day } \\
\hline B. havanaensis & $\begin{array}{l}0.403 \pm \\
0.031^{\mathrm{a}}\end{array}$ & $\begin{array}{l}0.174 \pm \\
0.020^{\mathrm{b}}\end{array}$ & - & $\begin{array}{l}0.252 \pm \\
0.017^{\mathrm{c}}\end{array}$ & $\begin{array}{l}0.078 \pm \\
0.017^{\mathrm{d}}\end{array}$ & - \\
\hline B. angularis & $\begin{array}{l}0.302 \pm \\
0.011^{\mathrm{a}}\end{array}$ & $\begin{array}{l}-0.076 \pm \\
0.019^{\mathrm{b}}\end{array}$ & - & $\begin{array}{l}0.233^{ \pm} \\
0.031^{\mathrm{a}}\end{array}$ & $\begin{array}{l}-0.146 \pm \\
0.010^{\mathrm{b}}\end{array}$ & - \\
\hline
\end{tabular}


0.001 two-way ANOVA). However, for B. angularis, it was only the diet type that had a significant effect on the peak population abundances; neither the presence of competitor nor the interaction of competitor $\mathrm{x}$ diet had any significant impact on this parameter $(p<0.05)$. The rate of population increase of both the rotifer species was significantly affected $(p<0.01)$ by the diet type and the competition, but the interaction was not $(p>0.05$, Table 2$)$.

\section{DISCUSSION}

The dominance of the typical American planktonic rotifer species, B. havanaensis, in the zooplankton of Lake Albufera suggests that it has an invasive tendency (Devin \& Beisel, 2007). It is often found in waterbodies dominated by toxic cyanobacteria (Nandini et al., 2005). Zooplankton composition of Lake Albufera over a three-decade period indicates the presence of

Table 2. Results of the two-way ANOVA conducted for the peak population density and the rate of population increase per day of Brachionus havanaensis (Bh) and Brachionus angularis (Ba) cultured separately or together (Factor A: competition) using Nannochloropsis oculata, Microcystis aeruginosa or on their mixed diet (Factor B: diet types). Resultados del ANOVA bidireccional realizado para la densidad máxima de población y la tasa de aumento de población por día de Brachionus havanaensis (Bh) y Brachionus angularis (Ba) cultivados por separado o juntos (Factor a: competición) usando Nannochloropsis oculata, Microcystis aeruginosa $o$ su mezcla como dieta (Factor B: tipos de dieta).

\section{Source of Variation}

$\mathrm{Bh}$

Competition (A)
Diet (B)
Interaction of A X B
Error

$\mathrm{Ba}$

Competition (A)

Diet (B)

Interaction of A X B

Error

\section{Rate of population increase}

$\mathrm{Bh}$

Competition (A)
Diet (B)
Interaction of A X B
Error

$\mathrm{Ba}$

$\begin{array}{rr}1 & 5645.734 \\ 2 & 13603.104 \\ 2 & 8685.165 \\ 18 & 1677.059\end{array}$
5645.734
6801.552
4342.582
93.170

\section{1}

2

2

2.100

2492.614

7.941

18

93.170

2.100

1246.307

3.970

$\begin{array}{ll}60.596 & <0.001 \\ 73.002 & <0.001 \\ 46.609 & <0.001\end{array}$

0.174

0.681

103.330

$<0.001$

0.329

0.724
Competition (A)
Diet (B)
Interaction of A X B
Error

12

1

$1 \quad 0.162$

0.061
0.162

0.003

$\begin{array}{lll}1 & 0.024 & 0.002\end{array}$
0.061
0.162
0.003

$\begin{array}{lll}1 & 0.024 & 0.002\end{array}$
$<0.001$

$<0.001$

0.234

$\begin{array}{rr}82.634 & <0.001 \\ 1.574 & 0.234\end{array}$


rotifer genera such as Keratella, Polyarthra and Anuraeopsis. Though several members of the genus Brachionus are commonly reported in this waterbody (Oltra et al., 2001), B. havanaensis was not observed from the extensive zooplankton collections carried out during 2010-2011 (Sarma et al., 2019) suggesting that this species was recently established in the Lake Albufera. Brachionus havanaensis is predominantly distributed in the Nearctic and Neotropical regions. Later, it was introduced into the Palearctic and Oriental regions (Segers, 2008). During the summer of 2015, we encountered much higher abundances of this species suggesting its ability to outcompete other members of Brachionus in this waterbody. Field collections from Mexican waterbodies too indicate its occurrence in relatively higher densities, ca. 1000 ind./1 during certain months (Nandini et al., 2016). There appear to be several factors favouring its dominance in different waterbodies: these include relatively higher resistance to natural toxins including cyanotoxins, higher population growth rates (Pavón-Meza et al., 2004, 2008) and non-preferred prey item for invertebrate predators such as larval insects and copepods (Enríquez-García et al., 2013).

Alva-Martínez et al. (2009) have shown that on a mixed diet consisting of a green alga and toxic Microcystis aeruginosa, the population of Brachionus calyciflorus crashed with increasing proportion of cyanobacteria in the diet, while under similar conditions, $B$. havanaensis showed consistently higher growth rates. Also, whether grown separately or together with B. calyciflorus, $B$. havanaensis was always numerically more abundant than the other competing brachionid rotifers regardless of the proportion of Microcyst$i$ is the diet. This confirms the resistance of $B$. havanaensis to $M$. aeruginosa over other brachionids. This is similar to our observations in this work where in the absence of competition when $B$. havanaensis was cultured on a mixed diet of Nannochloropsis and Microcystis, the population density was reduced to one-tenth; under comparable conditions, the population of $B$. angularis was reduced to one-twentieth. González-Pérez et al. (2018) have also documented that $B$. havanaensis is more resistant for two generations than another rotifer from the same family Brachionidae, Plationus patulus, when exposed to triclosan, an emerging contaminant in freshwater ecosystems. In the presence of strong invertebrate predators such as cyclopoids, B. havanaensis increases its growth rate than in the presence of less rapacious taxa such as turbellarians (Nandini et al., 2014). Although adult copepods such as Acanthocyclops, consume $B$. havanaensis (García et al., 2011), it is not a preferred item for many invertebrate predators (Nandini et al., 2003) possibly due to long posterior spines (Garza-Mouriño et al., 2005). In Lake Albufera, cyclopoids such as Acanthocyclops americanus are important predators that feed on rotifers including brachionids.

Competition for food between two (e.g., Sarma et al., 1999) or more (e.g., Fernández-Araiza et al., 2005) brachionid rotifers has received considerable attention since the seminal works on Brachionus rubens and B. calyciflorus by Rothhaupt (1988). These studies have shown that both biotic (e.g., food level, inoculation density) and abiotic (e.g., salinity, temperature) factors as well as species-specific characters (e.g., body size, intrinsic rate of population increase) influence the competitive outcome. Also, the presence of toxic substances, both xenobiotic (e.g., pharmaceuticals) and natural (e.g., cyanotoxins, salinity) are also known to affect the competition between two or more zooplankton species (Rebolledo et al., 2018). In the present work, the competitive outcome between $B$. havanaensis and $B$. angularis varied depending on the presence or absence of $M$. aeruginosa. In the absence of cyanobacteria, $B$. angularis had an adverse effect on $B$. havanaensis by reducing its population densities by about $90 \%$ and growth rates by about $65 \%$. On the other hand, under comparable conditions, $B$. havanaensis was able to affect adversely (by about $20 \%$ ) the growth rates but not the population abundances of $B$. angularis. However, in the presence of toxic Microcystis mixed with Nannochloropsis, the population of $B$. angularis completely crashed $(r$ being negative) before termination of the experiments, but under similar conditions, $B$. havanaensis was able to maintain its population with positive growth rates. These results suggest that 
higher abundances of $B$. havanaensis in Lake Albufera were not possibly due to its competitive superiority over $B$. angularis but the interference of toxicity from $M$. aeruginosa which favoured $B$. havanaensis. It is important to note that the toxic effects of M. aeruginosa on the responses of the population level responses of both $B$. angularis and $B$. havanaensis are possibly modulated by the presence of the green alga (Paerl, 2018). This is evident in mixed diet treatments containing the green alga which possibly minimized the adverse effects of Microcystis. The fact that both rotifer species died within a week when exposed to an exclusive diet of $M$. aeruginosa suggests that this strain of cyanobacterium was indeed toxic. This is further confirmed from previous studies from this waterbody where the microcystin concentration in the lake was as high as $16 \mu \mathrm{g} / 1$ (Romo et $a l ., 2008)$ and the inclusion of sonicated cells of $M$. aeruginosa in the diet significantly reduced the growth rates of the cladocerans (Nandini et al., 2017).

The peak population densities (up to 90 ind. $/ \mathrm{ml}$ ) observed here for $B$. havanaensis are not uncommon for this species under laboratory conditions. For example, Pavón-Meza et al. (2004) observed that $B$. havanaensis is capable of reaching extremely high densities (up to 600 ind. $/ \mathrm{ml}$ ) when fed on the green alga Chlorella. We were able to grow $B$. angularis to peak densities of about 20 ind./ml. Miracle et al. (2014) have cultured $B$. angularis isolated from Lake Albufera and fed on different size fractions of lake seston (0-15 $\mu \mathrm{m}$ particle size). They obtained peak population densities of about 20 ind./ml of $B$. angularis, similar to our observations in this study. The rate of population increase is yet another significant parameter often considered for interpreting the competitive outcome among different zooplankton species. For example, when Anuraeopsis fissa and B. calyciflorus were cultured together, the ability of the latter to replace the former was higher due to its higher population growth rates $(r=1.5$ per day) than that of A. fissa ( $r=0.9$ per day) (Sarma et al., 1996). In the present work, the $r$ of $B$. havanaensis varied from 0.25 to $0.40 / \mathrm{d}$ depending on the presence or the absence of the competitor. Pavón-Meza et al. (2004) reported the $r$ for this species in the range of 0.02 to 0.29 per day. For the strain of $B$. havanaensis we used here the $r$ was slightly higher, but within the range reported for Brachionus (0.12 to 3.7 per day, Miracle \& Serra, 1989). When Nannochloropsis alone was used as a diet, the $r$ of $B$. angularis varied from 0.23 to 0.30 per day which is within the range (0.07 - 0.35 per day) known for this species (Walz, 1987).

The present work suggests the possible adverse effects of the exotic $B$. havanaensis on locally occurring brachionid rotifers in interacting with cyanobacterial blooms, common in the lake Albufera (Vicente \& Miracle, 1992). Brachionus havanaensis, being pantropical (Segers, 2008), may easily colonize temperate waterbodies with the future projections of global warming (Hays et al., 2005). Increase in temperature also favours bloom formation in Microcystis. Thus, both these factors together may adversely impact locally adapted brachionids in freshwater ecosystems of temperate regions.

\section{CONCLUSIONS}

An increase in global trade and transport has increased the mobility of organisms and broken down ecological barriers to the transport of species around the world. Rotifers, in particular, are easily transported and established across the world (Duggan, 2010). The ability of $B$. havanaensis to withstand competition and predation pressure and grow on diets such as cyanobacteria indicates that it can be a successful invasive species and can survive in regions outside its native continent (Koste, 1978). Although originally reported from the Nearctic and neotropical regions, it is now found in Oriental and Palearctic regions (Segers, 2008). It has, however been suggested that the presence of the same species in different parts of the world could be a case of cryptic speciation as was the case in Brachionus plicatilis (Pociecha et al., 2007) and perhaps B. havanaensis is part of a species complex.

\section{ACKNOWLEDGEMENTS}

We thank two anonymous reviewers for improving our presentation. SSSS \& SN thank the 
programme PASPA (DGAPA) which supported our stay at the University of Valencia, Burjassot (Valencia), Spain.

\section{REFERENCES}

ALVA-MARTÍNEZ, A. F., SARMA, S. S. S. \& NANDINI, S. 2007 Effect of mixed diets (cyanobacteria and green algae) on the population growth of the cladocerans Ceriodaphnia dubia and Moina macrocopa. Aquatic Ecology, 41(4):579-585. DOI: 10.1007/s10452-0079115-1

ALVA-MARTÍNEZ, A. F., R. FERNÁNDEZ, R., S. S. S. SARMA \& S. NANDINI. 2009. Effect of mixed toxic diets (Microcystis and Chlorella) on the rotifers Brachionus calyciflorus and Brachionus havanaensis cultured alone and together. Limnologica, 39(4):302-305. DOI: 10.1016/j.limno.2009.06.002

BOROWITZKA, M. A. \& L. J. BOROWITZKA. 1988. Micro-algal biotechnology. Cambridge University Press, London.

DEVIN, S. \& BEISEL, J.-N. 2007. Biological and ecological characteristics of invasive species: a gammarid study. Biological Invasions, 9:13-24.

DUGGAN, I. C. 2010. The freshwater aquarium trade as a vector for incidental invertebrate fauna. Biological Invasions, 12:3757-3770. DOI: $10.1007 / \mathrm{s} 10530-010-9768-\mathrm{x}$

ENRÍQUEZ-GARCÍA, C., S. NANDINI \& S. S. S. SARMA. 2013. Feeding behaviour of Acanthocyclops americanus (Marsh) (Copepoda: Cyclopoida). Journal of Natural History, 47(5-12):853-862. DOI: 10.1080/ 00222933.2012 .747636

FERNÁNDEZ-ARAIZA, M. A., S. S. S. SARMA $\&$ S. NANDINI. 2005. Combined effects of food concentration and temperature on competition among four species of Brachionus (Rotifera). Hydrobiologia, 546:519-534. DOI: 10.1007/s10750-005-4295-y

GARCÍA, C. E., S. NANDINI \& S. S. S. SARMA. 2011. Demographic characteristics of the copepod Acanthocyclops americanus (Sars, 1863) (Copepoda: Cyclopoida) fed mixed algal (Scenedesmus acutus)-rotifer (Brachionus havanaensis) diet. Hydrobiolo- gia, 666:59-69. DOI: 10.1007/s10750-0100209-8

GARZA-MOURIÑO, G., M. SILVA-BRIANO, S. NANDINI, S. S. S. SARMA \& M. E. CASTELLANOS-PÁEZ. 2005. Morphological and morphometrical variations of selected rotifer species in response to predation: a seasonal study of selected brachionid species from Lake Xochimilco (Mexico). Hydrobiologia, 546:169-179. DOI: 10.1007/s10750005-4114-5

GILBERT, J. J. 1985. Competition between rotifers and Daphnia. Ecology, 66(6): 1943-1950. DOI: 10.2307/2937390

GONZÁLEZ-PÉREZ, B. K., S. S. S. SARMA, M. E. CASTELLANOS-PÁEZ \& S. NANDINI. 2018. Multigenerational effects of triclosan on the demography of Plationus patulus and Brachionus havanaensis (Rotifera). Ecotoxicology and Environmental Safety, 147: 275-282. DOI: 10.1016/j.ecoenv.2017.08.049

HAYS, G. C., A. J. RICHARDSON \& C. ROBINSON. 2005. Climate change and marine plankton. TRENDS in Ecology and Evolution, 20(6):337-344. DOI: 10.1016/j. tree.2005.03.004

KOSTE, W. 1978. Rotatoria. Die Rädertiere Mitteleuropas bergründet von Max Voigt-Monogononta. 2nd ed. Gebrüder Borntraeger, Berlin and Stuttgart. 2 vols.

LIN, Q., S. S. S. SARMA, S. NANDINI \& B. P. HAN. 2014. Effect of cyanobacterium on competition between rotifers: a population growth study. Inland Waters, 4(3):319-326. DOI: $10.5268 / \mathrm{IW}-4.3 .547$

MACISAAC, H. J. \& J. J. GILBERT. 1989. Competition between rotifers and cladocerans of different body sizes. Oecologia, 81:295-301. DOI: 10.1007/BF00377074

MIRACLE, M. R. \& M. SERRA. 1989. Salinity and temperature influence in rotifer life history characteristics. Hydrobiologia, 186(1): 81-102. DOI: 10.1007/BF00048900

MIRACLE, M. R., E. VICENTE, S. S. S. SARMA \& S. NANDINI. 2014. Planktonic rotifer feeding in hypertrophic conditions. International Review of Hydrobiology 99: 141-150. DOI: 10.1002/iroh.201301714

NANDINI, S., R. PÉREZ-CHÁVEZ \& S. S. S. 
SARMA. 2003. The effect of prey morphology on the feeding behaviour and population growth of the predatory rotifer Asplanchna sieboldi: A case study using five species of Brachionus (Rotifera). Freshwater Biology, 48(12):2131-2140. DOI: 10.1046/j.13652427.2003.01149.x

NANDINI, S., P. RAMÍREZ-GARCÍA \& S. S. S. SARMA. 2005. Seasonal variations in the species diversity of planktonic rotifers in Lake Xochimilco, Mexico. Journal of Freshwater Ecology 20(2):287-294. DOI: 10.1080/ 02705060.2005 .9664968

NANDINI, S., C. ENRÍQUEZ-GARCÍA \& S. S. S. SARMA. 2007. A laboratory study on the demography and competition of three species of littoral cladocerans from Lake Huetzalin, Xochimilco, Mexico. Aquatic Ecology, 41(4):547-556. DOI: 10.1007/s10452-0079116-0

NANDINI, S., F. S. ZÚÑIGA-JUÁREZ \& S. S. S. SARMA. 2014. Direct and indirect effects of invertebrate predators on population level responses of the rotifer Brachionus havanaensis (Rotifera). International Review of Hydrobiology, 99:107-116. DOI: 10.1002/iroh. 201301709

NANDINI, S., P. RAMÍREZ-GARCÍA \& S. S. S. SARMA. 2016. Water quality indicators in Lake Xochimilco, Mexico: zooplankton and Vibrio cholera. Journal of Limnology, 75(1):91-100. DOI: 10.4081/jlimnol.2015. 1213

NANDINI, S., M. R. MIRACLE, E. VICENTE, S. S. S. SARMA \& R. D. GULATI. 2017. Microcystis extracts and single cells have differential impacts on the demography of cladocerans: a case study on Moina cf. micru$r a$ isolated from the Mediterranean coastal shallow lake (L'Albufera, Spain). Hydrobiologia, 798(1):127-139. DOI: 10.1007/s10750016-2665-2

OLTRA, R., M. T. ALFONSO, M. SAHUQUILLO \& M. R. MIRACLE. 2001. Increase of rotifer diversity after sewage diversion in the hypertrophic lagoon, Albufera of Valencia, Spain. Hydrobiologia, 446(447):213-220. DOI: 10.1023/A:10175678

PAERL, H. W. 2018. Mitigating toxic planktonic cyanobacterial blooms in aquatic ecosystems facing increasing anthropogenic and climatic pressures. Toxins 2018, 10, 76; DOI: 10.3390/ toxins10020076

PAVÓN-MEZA, E. L., S. S. S. SARMA \& S. NANDINI. 2004. Combined effects of food (Chlorella vulgaris) concentration and temperature on the population growth of Brachionus havanaensis (Rotifera: Brachionidae). Journal of Freshwater Ecology, 19(4):521-530. DOI: 10.1080/02705060.2004.9664731

PAVÓN-MEZA, E. L., S. S. S. SARMA \& S. NANDINI. 2008. Combined effects of temperature, food availability and predator's (Asplanchna girodi) allelochemicals on the demography and population growth of Brachionus havanaensis (Rotifera). Allelopathy Journal, 21(1):95-106.

POCIECHA, A., W. SOLARZ, K. NAJBEREK \& E. WILK-WOZNIAK. 2016. Native, alien, cosmopolitan, or cryptogenic? A framework for clarifying the origin status of rotifers. Aquatic Biology, 24:141-149. DOI: 10.3354/ ab00644

REBOLlEDO, U. A., S. NANDINI, S. S. S. SARMA, J. C. R. REYES \& G. A. R. MONTES DE OCA. 2018. Demographic and competition studies on Brachionus ibericus and Proales similis in relation to salinity and algal (Nannochloropsis oculata) density. Aquaculture International, 26(2): 629-644. DOI: $10.1007 / \mathrm{s} 10499-017-0233-\mathrm{Z}$

ROMO, S., A. GARCÍA-MURCIA, M. J. VILLENA, V. SÁNCHEZ \& A. BALLESTER. 2008. Tendencias del fitoplancton en el lago de la Albufera de Valencia e implicaciones para su ecología, gestión y recuperación. Limnetica, 27(1):11-28.

ROTHHAUPT, O. 1988. Mechanistic resource competition theory applied to laboratory experiments with zooplankton. Nature, 333:660-662. DOI: 10.1038/333660a0

SARMA, S. S. S., N. IYER \& H. J. DUMONT. 1996. Competitive interactions between herbivorous rotifers: importance of food concentration and initial population density. Hydrobiologia, 331:1-7. DOI: 10.1007/BF00025402

SARMA, S. S. S., M. A. FERNÁNDEZ-ARAIZA \& S. NANDINI. 1999. Competition between 
Brachionus calyciflorus Pallas and Brachionus patulus (Müller) (Rotifera) in relation to algal food concentration and initial population density. Aquatic Ecology, 33(4):339-345. DOI: 10.1023/A:1009912816400

SARMA, S. S. S., M. R. MIRACLE, S. NANDINI \& E. VICENTE. 2019. Predation by Acanthocyclops americanus (Copepoda: Cyclopoida) in the hypertrophic shallow waterbody, Lake Albufera (Spain): field and laboratory observations. Hydrobiologia (in press). DOI: 10.1007/s10750-018-3546-7

SEGERS, H. 2008. Global diversity of rotifers (Rotifera) in freshwater. Hydrobiologia, 595:49-59. DOI: 10.1007/s10750-007-9003-7

SIBLY, R. M. \& J. HONE, 2002. Population growth rate and its determinants: an overview. Philosophical Transactions of the Royal Society, London B: Biological, 357:1153-1170. DOI: 10.1098/rstb.2002.1117 SIKORA, A. \& P. DAWIDOWICZ. 2017. Breakage of cyanobacterial filaments by small- and large sized Daphnia: are there any temperature-dependent differences? Hydrobiologia, 798:119-126. DOI: 10.1007/s10750015-2436-5

SMITH, D. W. \& S. D. COOPER. 1982. Competition among Cladocera. Ecology, 63(4):1004-1015. DOI: 10.2307/1937240

VANNI, M. J. 1986. Competition in zooplankton communities: Suppression of small species by Daphnia pulex. Limnology and Oceanography, 31(5):1039-1056.

VICENTE, E. \& M. R. MIRACLE. 1992. The coastal lagoon Albufera de Valencia: an ecosystem under stress. Limnetica, 8:87-100.

WALZ, N., 1987. Comparative population dynamics of the rotifers Brachionus angularis and Keratella cochlearis. Hydrobiologia, 147:209-213. DOI: 10.1007/BF00025744

WEBER, C. I. 1993. Methods for measuring the acute toxicity of effluents and receiving waters to freshwater and marine organis$m s$. 4th ed. United States Environmental Protection Agency, Cincinnati, Ohio, EPA/600/4-90/027F.

Con el apoyo de:
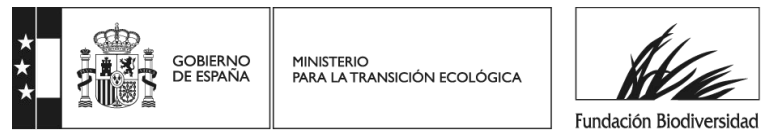